ORIGINAL ARTICLE

\title{
Diversity of metazoan parasites in Colossoma macropomum (Serrasalmidae) from the lower Jari River, a tributary of the Amazonas River in Brazil
} \author{
Gracienhe Gomes SANTOS ${ }^{1}$, Marcos TAVARES-DIAS ${ }^{*}$ \\ Faculdade de Macapá (FAMA), Macapá, AP, Brasil \\ 2 Embrapa Amapá, Macapá, AP, Brasil \\ ${ }^{3}$ Universidade do Estado do Amapá (UEAP), Macapá, AP, Brasil \\ * Corresponding author: marcos.tavares@embrapa.br
}

Bianca Barata GONÇALVES ${ }^{1}$, Marcos Sidney Brito OLIVEIRA², William Felix BORGES³,

\begin{abstract}
This study investigated the diversity of metazoan parasites in Colossoma macropomum from the Jari River, in the eastern Amazon, northern Brazil. We collected a total of 4966 parasites from 34 fishes, including monogeneans (Anacanthorus spathulatus, Mymarothecium boegeri, Notozothecium janauachensis and Linguadactyloides brinkmanni), nematodes (Spectatus spectatus larvae, Contracaecum sp. larvae andProcamallanus (Spirocamallanus) inopinatus), digeneans (Cladorchiidae metacercariae), acanthocephalans (Neoechinorhynchus buttnerae), crustaceans (Ergasilus turucuyus, Argulus multicolor, Perulernaea gamitanae and Braga patagonica), mites and leeches. The dominance was of monogenean species, found in the gills of the hosts. The parasites exhibited high aggregate dispersion, except Contracaecum sp. and $P$. (S.) inopinatus, that showed uniform and random dispersion, respectively. The species richness of parasites varied from 1 to 9 , the Brillouin diversity index from 0 to 1.52, evenness from 0 to 0.63 and the Berger-Parker dominance index from 0.39 to 1.00 . Abundance of parasites was not influenced by host length, but there was significant correlation with host body weight in some cases. The parasite community was characterized by low species richness and moderate diversity, with a predominance of ectoparasites with high prevalence and abundance, as well as the presence of endoparasites in the larval stage.
\end{abstract}

KEYWORDS: aggregation, diversity, endoparasites, freshwater fish

\section{Diversidade de parasitos metazoários em Colossoma macropomum (Serrasalmidae) do baixo Rio Jari, um tributário do Rio Amazonas no Brasil}

\section{RESUMO}

Este estudo investigou a diversidade de parasitos metazoários em Colossoma macropomum do Rio Jari, na Amazônia oriental, norte do Brasil. Foram coletados um total de 4.966 parasitos, incluindo monogeneas (Anacanthorus spathulatus, Mymarothecium boegeri, Notozothecium janauachensis e Linguadactyloides brinkmanni), nematoides (larvas de Spectatus spectatus, larvas de Contracaecum sp. eProcamallanus (Spirocamallanus) inopinatus), digeneas (metacercárias de Cladorchiidae), acantocéfalos (Neoechinorhynchus buttnerae), crustáceos (Ergasilus turucuyus, Argulus multicolor, Perulernaea gamitanae e Braga patagonica), ácaros e sanguessugas. A dominância foi de espécies de monogeneas, encontradas nas brânquias dos hospedeiros, e houve elevada dispersão agregada dos parasitos, exceto Contracaecum sp., que teve dispersão uniforme e $P$. $(S$.) inopinatus, que mostrou dispersão randômica. A riqueza de espécies de parasitos variou de 1 a 9, o índice de diversidade de Brillouin de 0 a 1,52, a uniformidade de 0 a 0,63 e o índice de dominância de Berger-Parker de 0,39 a 1,00. A abundância de parasitos não foi influenciada pelo comprimento dos hospedeiros, mas houve significativa correlação com o peso corporal em alguns casos. A comunidade parasitária foi caracterizada por baixa riqueza de espécies e moderada diversidade, com predominância de ectoparasitos com elevada prevalência e abundância, bem como pela presença de endoparasitos em estágio larval.

PALAVRAS-CHAVE: agregação, diversidade, endoparasitos, peixe de água doce

CITE AS: Gonçalves, B. B.; Oliveira, M. S. B.; Borges, W. F.; Santos, G. G.; Tavares-Dias, M. 2018. Diversity of metazoan parasites in Colossoma macropomum (Serrasalmidae) from the lower Jari River, a tributary of the Amazonas River in Brazil. Acta Amazonica 48: 211-216. 


\section{INTRODUCTION}

Fish are the main sources of protein for many Amazonian riverine populations, which have the highest per capita fish consumption in the world (Petrere Júnior et al. 2007; Isaac et al. 2015). Many species of different Characiformes fish are consumed in the Amazon region, mainly Colossoma macropomum Cuvier, 1818, known locally as tambaqui. This omnivorous fish is exclusively frugivorous during the adult phase and, during the juvenile phase, tends to feed on zooplankton, mainly on cladocerans, copepods and chironomids (Soares et al. 2011; Morais and O'Sullivan 2017). One important point that has been highlighted is the trophic level of the wild fish population in determining the abundance and species richness of parasites (Takemoto et al. 2009; Poulin and Leung 2011; Oliveira et al. 2017; Tavares-Dias et al. 2017).

Parasitism is one of the most common lifestyles on Earth, but parasites are rarely included in the studies (Chambouvet et al. 2015; Oliveira et al. 2017). The parasitic fauna of $C$. macropomum has been studied in floodplain lakes of the middle and lower Solimôes River (Malta 1984; Morey and Malta 2016), and in the lower Amazonas River, in the state of Pará (Fischer et al. 2003) These studies reported that wild C. macropomum populations harbor ectoparasite and endoparasite species of diverse taxa, which display a variety of strategies in their life cycles, which may be either direct or indirect. In fish, body size of hosts has emerged also as a significant predictor of the burden of parasites (Poulin 2004; Poulin and Leung 2011). In addition, factors such as the ecology of both freshwater fish and parasites, as well as environmental conditions, influence parasite fauna in populations of wild fish (Fischer et al. 2003; Poulin and Leung 2011; Oliveira et al. 2017; Tavares-Dias et al. 2017). Considering the wide distribution of tambaqui in Amazon river systems, the parasitic fauna of natural populations of tambaqui has been little addressed. The aim of this study was therefore to investigate the parasitic fauna of metazoans in C. macropomum from the lower Jari River, a tributary of the Amazonas River in the State of Pará, northern Brazil.

\section{MATERIAL AND METHODS}

\section{Fish and collection site}

Between October and December 2016 (low river season), 34 specimens of $C$. macropomum $(29.8 \pm 5.6 \mathrm{~cm}$ total length and $774.8 \pm 481.9 \mathrm{~g}$ body mass) were collected in the lower Jari River, in the municipality of Gurupá, State of Pará, northern Brazil (Figure 1). The fish were caught using gill nets, with mesh sizes from 50 to $70 \mathrm{~mm}$, under authorization of ICMBio license \# 44268-4.

The Jari River is an important tributary of the Amazonas River in the eastern Amazon, Brazil. It rises in the Park of the Tumucumaque Mountains, on the Suriname-Brazil border and flows to the South of the state of Amapá. The basin of the Jari
River from its mouth is strongly influenced by the daily tides of the Amazonas River (EPE 2011) and by the presence of a varied amount of suspended organic matter (Abreu and Cunha 2015).

This study was developed in accordance with the principles recommended by the Brazilian College of Animal Experimentation (Cobea) and with the authorization from Ethics Committee in the Use of Animals of Embrapa Amapá (\# 004 - CEUA/CPAFAP).

\section{Collection and analysis of parasites}

The fish were weighed $(\mathrm{g})$ and measured in length $(\mathrm{cm})$, and necropsied for parasitological analysis. We examined the mouth, opercula, gills, viscera and gastrointestinal tract of each fish. Gills were removed for collection of ectoparasites, and the gastrointestinal tract and viscera were removed and examined for endoparasites using stereomicroscopy. The collection, fixation, preservation, counting and staining of the parasites for identification followed Eiras et al. (2006).

The ecological indices calculated for the parasite infracommunities followed Bush et al. (1997). We used the Diversity software (Pisces Conservation Ltd., UK) to calculate the following descriptors for the parasite community: species richness of parasites, the Brillouin diversity index $(H B)$, evenness $(E)$ in association with the diversity index, the Berger-Parker dominance index $(d)$, and the dominance frequency (percentage of the infracommunities in which a parasite species is numerically dominant) (Rohde et al. 1995; Magurran 2004). In order to detect the distribution pattern of the parasite infracommunities (Rózsa et al. 2000), the index of dispersion (ID) and the Poulin discrepancy index (D) were calculated using the Quantitative Parasitology 3.0 software for species with prevalence $>10 \%$. The ID significance for each infracommunity was tested using the $d$-statistics (Ludwig and Reynolds 1988). The correlation of the parasites abundance with length and weight of hosts, as well as with the species richness and the Brillouin diversity index was analyzed using the Spearman correlation coefficient (rs) (Zar 2010).

\section{RESULTS}

All the fish examined were parasitized by species of Monogenea, Nematoda, Acanthocephala, Digenea, Crustacea, Acarina and Hirudinea, but the dominance was of monogenean species (Table 1). The parasites presented aggregate dispersion, except for Contracaecum sp., that had uniform dispersion, and Procamallanus (S.) inopinatus that had random dispersion (Table 2). A total of 4966 parasites were collected, between ecto- and endoparasites, but the component community was dominated by ectoparasite species. Percentage of ectoparasites was $73.3 \%$ and percentage of endoparasites was $26.7 \%$. In addition, four species of endoparasites larvae were found.

The species richness varied between 1 and $9(4.9 \pm 1.9)$, the Brillouin index between 0 and $1.52(0.80 \pm 0.42)$, evenness 


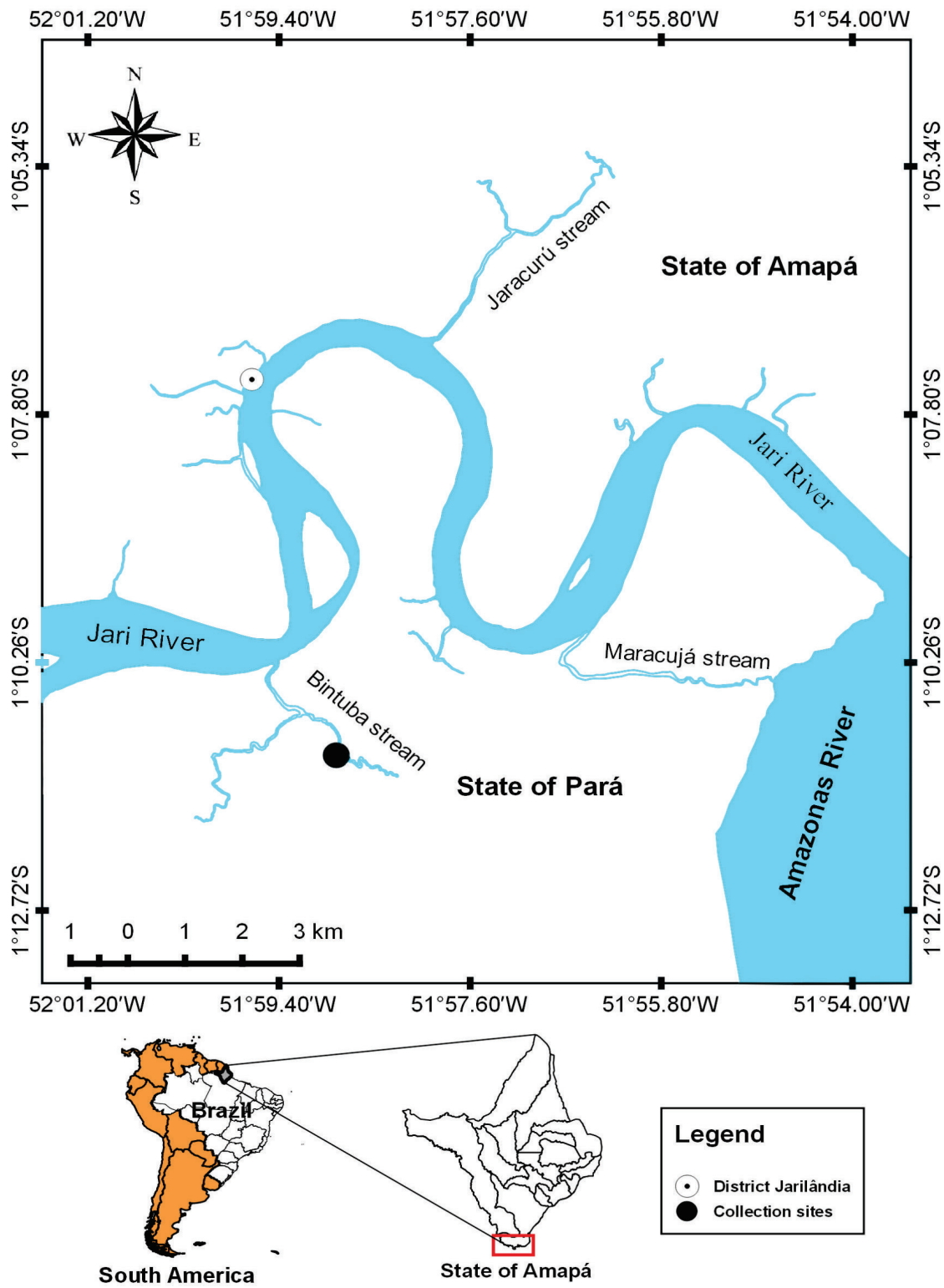

Figure 1. Site of collection of Colossoma macropomum for parasitological analyses in the lower Jari River, and its location in the south of the state of Pará, in northern Brazil. This figure is in color in the electronic version.

between 0 and $0.63(0.31 \pm 0.17)$ and the Berger-Parker dominance index between 0.39 and $1.00(0.69 \pm 0.21)$. There was a predominance of hosts with $4-6$ species of parasites (Figure 2). The length and body weight of the hosts was significantly and positively correlated with species richness of parasites $(r s=$ $0.38, \mathrm{p}=0.02$, and $r s=0.53, \mathrm{p}=0.001$, respectively), but had no significant correlation with the Brillouin diversity index ( $r s=$ $0.21, \mathrm{p}=0.23$, and $r s=0.23, \mathrm{p}=0.19$, respectively).

The length of hosts was not correlated with the abundance of parasite species, but the body weight showed a weak positive correlation only with the abundance of $M$. bogeri $(r s=0.36$, $\mathrm{p}$ $=0.04)$ and L. brinkmanni ( $r s=0.45, \mathrm{p}=0.009)$, and positive correlation with the abundance of $E$. turucuyus $(r s=0.52, \mathrm{p}=0.02)$.

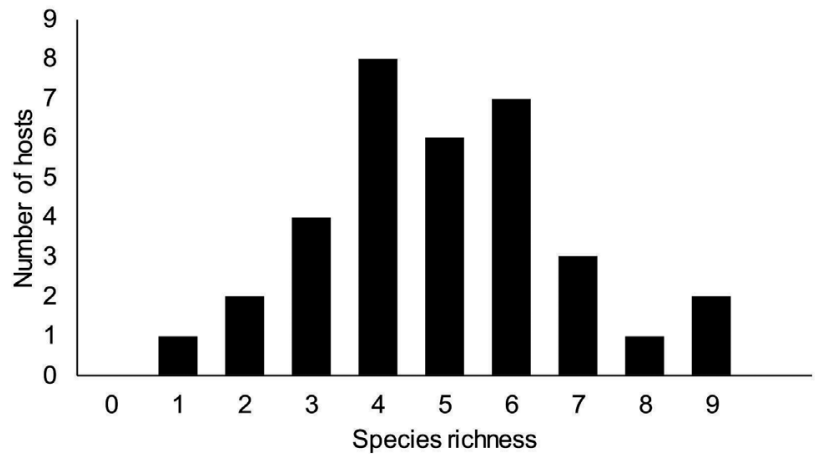

Figure 2. Species richness of metazoan parasites in Colossoma macropomum from the lower Jari River, in the state of Pará (Brazil). 
Table 1. Metazoan parasites of Colossoma macropomum from the lower Jari River, state of Pará (Brazil). P: Prevalence, MI: Mean intensity, MA: Mean abundance, FD: Frequence of dominance, TNP: Total number of parasites, Sl: Site of infection.

\begin{tabular}{|c|c|c|c|c|c|c|c|}
\hline Species of parasites & $\mathrm{P}(\%)$ & $\mathrm{Ml}$ & $\mathrm{MA} \pm \mathrm{SD}$ & $\mathrm{FD}(\%)$ & Range & TNP & $\mathrm{SI}$ \\
\hline \multicolumn{8}{|l|}{ Monogenea } \\
\hline Anacanthorus spathulatus & 100 & 105.7 & $105.7 \pm 118.4$ & 0.72 & $6-520$ & 3593 & Gills \\
\hline Mymarothecium boegeri & 64.7 & 19.9 & $12.9 \pm 19.7$ & 0.09 & $1-91$ & 437 & Gills \\
\hline Notozothecium janauachensis & 82.4 & 11.6 & $9.6 \pm 11.9$ & 0.07 & $1-55$ & 325 & Gills \\
\hline Linguadactyloides brinkmanni & 55.9 & 10.5 & $5.9 \pm 8.7$ & 0.04 & $1-26$ & 199 & Gills \\
\hline \multicolumn{8}{|l|}{ Nematoda } \\
\hline Spectatus spectatus (larvae) & 2.9 & 0.1 & $0.03 \pm 0.2$ & & $1-1$ & 1 & Cecum pyloric \\
\hline Spectatus spectatus (larvae) & 2.9 & 0.1 & $0.03 \pm 0.2$ & - & $1-1$ & 1 & Intestine \\
\hline Contracaecum sp. (larvae) & 11.8 & 0.3 & $0.1 \pm 0.4$ & - & $1-2$ & 5 & Cecum pyloric \\
\hline Contracaecum sp. (larvae) & 26.5 & 2.0 & $1.1 \pm 3.7$ & 0.01 & $1-21$ & 38 & Intestine \\
\hline Contracaecum sp. (larvae) & 2.9 & 0.1 & $0.03 \pm 0.2$ & - & $1-1$ & 1 & Gallbladder \\
\hline Procamallanus (S.) inopinatus (larvae and adults) & 2.9 & 0.1 & $0.03 \pm 0.2$ & - & $1-1$ & 1 & Stomach \\
\hline Procamallanus (S.) inopinatus (larvae and adults) & 23.5 & 0.9 & $0.5 \pm 1.1$ & - & $1-4$ & 18 & Intestine \\
\hline Procamallanus (S.) inopinatus (larvae and adults) & 14.7 & 0.4 & $0.2 \pm 0.7$ & - & $1-3$ & 8 & Cecum pyloric \\
\hline \multicolumn{8}{|l|}{ Digenea } \\
\hline Metacercariae of Cladorchiidae & 17.6 & 3.4 & $1.9 \pm 6.6$ & 0.01 & $1-33$ & 65 & Gills \\
\hline Metacercariae of Cladorchiidae & 2.9 & 0.2 & $0.1 \pm 0.7$ & - & $1-4$ & 4 & Cecum pyloric \\
\hline Metacercariae of Cladorchiidae & 5.9 & 6.7 & $3.7 \pm 21.4$ & 0.03 & $1-125$ & 127 & Intestine \\
\hline \multicolumn{8}{|l|}{ Ananthocephala } \\
\hline Neoechinorhynchus buttnerae & 11.8 & 2.2 & $1.2 \pm 4.4$ & 0.01 & $1-22$ & 41 & Intestine \\
\hline Neoechinorhynchus buttnerae & 2.9 & 0.1 & $0.03 \pm 0.2$ & - & $1-1$ & 1 & Cecum pyloric \\
\hline Neoechinorhynchus buttnerae & 2.9 & 0.1 & $0.03 \pm 0.2$ & - & $1-1$ & 1 & Stomach \\
\hline \multicolumn{8}{|l|}{ Crustacea } \\
\hline Ergasilus turucuyus & 23.5 & 1.6 & $0.9 \pm 1.9$ & 0.01 & $1-8$ & 31 & Gills \\
\hline Argulus multicolor & 2.9 & 0.1 & $0.03 \pm 0.2$ & - & $1-1$ & 1 & Mouth \\
\hline Argulus multicolor & 2.9 & 0.2 & $0.1 \pm 0.7$ & - & $1-4$ & 4 & Gills \\
\hline Perulernaea gamitanae & 2.9 & 0.1 & $0.03 \pm 0.2$ & & $1-1$ & 1 & Mouth \\
\hline Braga patagonica & 5.9 & 0.1 & $0.1 \pm 0.2$ & - & $1-1$ & 2 & Fin \\
\hline \multicolumn{8}{|l|}{ Arachnida } \\
\hline Acarina gen. sp. & 41.2 & 3.1 & $1.7 \pm 2.6$ & 0.01 & $1-9$ & 58 & Gills \\
\hline \multicolumn{8}{|l|}{ Hirudinea } \\
\hline Leeches & 5.9 & 0.2 & $0.1 \pm 0.4$ & - & $1-2$ & 3 & Gills \\
\hline
\end{tabular}

Table 2. Dispersion index (ID), statistic- $d$ and discrepancy index (D) of the infracommunities of metazoan parasites of Colossoma macropomum from the lower Jari River, state of Pará (Brazil).

\begin{tabular}{lcccc}
\hline Parasite Species & ID & $d$ & D & Dispersion \\
\hline Anacanthorus spathulatus & 3.306 & 6.71 & 0.362 & Aggregated \\
Mymarothecium bogeri & 2.198 & 3.98 & 0.526 & Aggregated \\
Notozothecium januachensis & 2.329 & 4.32 & 0.448 & Aggregated \\
\hline Linguadactyloides brinkmanni & 2.807 & 5.55 & 0.618 & Aggregated \\
Neoechinorhynchus buttnerae & 2.570 & 4.96 & 0.870 & Aggregated \\
Contracaecum sp. & 0.753 & -1.02 & 0.624 & Uniform \\
Procamallanus (S.) inopinatus & 1.489 & 1.85 & 0.771 & Random \\
Metacercariae of Cladorchiidae & 2.732 & 5.36 & 0.817 & Aggregated \\
Ergasilus turucuyus & 1.587 & 2.17 & 0.793 & Aggregated \\
Acarigen. sp. & 1.662 & 2.41 & 0.678 & Aggregated \\
\hline
\end{tabular}




\section{DISCUSSION}

In wild fish populations, richness and diversity of parasites are affected by the relationship of the parasite community with the trophic level and life stage of the host, physical and chemical environmental factors, and presence of viable intermediate hosts (Takemoto et al. 2009; Fischer et al. 2003; Tavares-Dias et al. 2017; Oliveira et al. 2017). Colossoma macropomum from the lower Jari River were parasitized by four species of monogeneans, three nematodes, one acanthocephalan, one digenean, four crustaceans, one mite and one leech, but with dominance of monogeneas and overdispersion of parasites. For C. macropomum from the middle Solimóes River and lower Amazonas River, three species of monogeneans, two nematodes, acanthocephalan, one digenean and two crustaceans were reported (Fischer et al. 2003). The diversity of endoparasites in C. macropomum is due to the mode of life of this migrating fish, and mainly to its diet in the juvenile phase, that consists mainly of cladocerans, copepods and chironomids (Soares et al. 2011; Morais and O'Sullivan 2017), which are intermediate hosts of endoparasites.

Monogeneans are common ectoparasites in the parasitic community of freshwater fish in various lentic environments, which favor the swimming of the larval form (oncomiracidium) to find hosts in their direct life cycle (Dogiel 1961; Tavares-Dias et al. 2017). Populations of $C$. macropomum, as the one studied here, prefer sites with nutrient-rich waters and near the margin of rivers and lakes (Morais and O'Sullivan 2017), which would explain the diversity and dominance of monogeneans in the Jari River. The levels of infection by monogeneans in our samples were higher than those described by Fischer $e t$ al. (2003) for $C$. macropomum in the Amazonas and Solimões rivers, and may be due to differences in environmental conditions.

Larvae of Spectatus spectatus, Contracaecum sp. and Procamallanus (Spirocamallanus) inopinatus were found in $C$. macropomum from the Jari River. Fischer et al. (2003) reported parasitism by Procamallanus sp. and Spirocamallanus sp. in C. macropomum from the Solimões and Amazonas rivers. The level of $N$. buttnerae infection in C. macropomum from the Jari River was lower than that found by Fischer $e t$ al. (2003). Infections by endoparasite species depend on the presence of infective stages in the environment, and the amount of contaminated ingested food items (Oliveira et al. 2017; Tavares-Dias et al. 2017). Neoechinorbynchus buttnerae were found to accumulate in the $C$ macropomum population with the growth of the host individuals (Fischer et al. 2003). Severe tissue alterations occurred in the intestine of $C$. macropomum in association with $N$. buttnerae, including desquamation, abrasion, compression, hypertrophy of goblet cells and disappearance of villi on the mucosa, leukocyte infiltration in the submucosa and muscle layer, metaplasia with loose connective tissue substitution, edema of blood vessels and necrotic foci (Matos et al. 2017).

Metacercariae of Cladorchiidae were found in the gills, intestine and pyloric cecum of C. macropomum from the Jari
River, and with higher level of infection then that found in a single individual from the Solimões River (Fischer et al. 2003). These digeneans have a complex life cycle. The cercariae of Cladorchiidae emerge from mollusks, the intermediate host and are eaten by a crustacean, which, in turn, is eaten by the definitive host fish (Bullard and Overstreet 2008), such as C. macropomum, to complete its life cycle.

The community of crustaceans in C. macropomum from the Jari River was composed of Ergasilus turucuyus, A. multicolor, P. gamitanae and Braga patagonica, with dominance of $E$. turucuyus. Fischer et al. (2003) reported low infestation of G. jaraquensis and P. gamitanae, and Malta (1984) found low infestation of Dolops carvalhoi, A. multicolor and Argulus sp. in C. macropomum. However, only the abundance of E. turucuyus had a significant positive correlation with the body weight of the hosts. Host body size generally explains only a portion of the interspecific variance in the numbers of parasite species infecting different host species (Poulin 2004; Poulin and Leung 2011), because correlation of parasite abundance with host body size is not universal (Poulin 2004).

We found mites on the gills of C. macropomum. In fish, mites are usually found in the gills, integument, and digestive tract, but there are few records of encapsulated larvae on the wall of the pharynx and esophagus, and adults in a variety of vertebrates, including fish and piscivorous birds (Lizama $e t$ al. 2013). Takemoto et al. (2009) also reported infestation of mites in Geophagus proximus and Serrasalmus marginatus from the Paraná River (Brazil). This low infection by leeches in the gills of C. macropomum may have been accidental. Similar findings have been also reported by Morey and Malta (2016) for C. macropomum.

\section{CONCLUSIONS}

The parasitic community of Colossoma macropomum in the lower Jari River was characterized by the first time, and ectoparasites with high prevalence and abundance, as well as endoparasites in the larval stage were found. This was the first report of Ergasilus turucuyus for C. macropomum. There was a high overdispersion of parasites, low parasite species richness and low evenness, but with moderate Brillouin diversity. Finally, host size was not a factor structuring the parasite community, because the length of hosts did not influence parasite abundance, while body weight of hosts had little influence on abundance.

\section{ACKNOWLEDGMENTS}

M. Tavares-Dias was granted a research fellowship (\# 303013/2015-0) from Conselho Nacional de Desenvolvimento Científico e Tecnológico (CNPq, Brazil). B.B. Gonçalves was granted an undergraduate scholarship from CNPq. 


\section{REFERENCES}

Abreu, C.H.M.; Cunha A.C. 2015. Qualidade da água em ecossistemas aquáticos tropicais sob impactos ambientais no baixo Rio Jari-AP: Revisão descritiva. Biota Amazônia, 5: 119-131.

Bullard, S.A.; Overstreet, R.M. 2008. Digeneans as enemies of fishes. In: Eiras, J.C.; Segner, H.; Wahli, T.; Kapoor, B.G. (Ed.). Fish diseases. Sciences publishers, Plymouth, p.817-976.

Bush, A.O.; Lafferty, K.D.; Lotz, J.M.; Shostak, W. 1997. Parasitology meets ecology on its own terms: Margolis et al. revisited. Journal of Parasitology, 83: 575-583.

Chambouvet, A.; Richards, T.A.; Bass, D.; Neuhauser, S. 2015. Revealing microparasite diversity in aquatic environments using brute force molecular techniques and subtle microscopy. In: Morand, S.; Krasnov, B.R.; Littlewood, D. T. J. (Ed). Parasite diversity and diversification: evolutionary ecology meets phylogenetics. Cambridge University Pres, Padstow Cornwall, p.93-116.

Choudhury, A.; Aguirre-Macedo, M.L.; Curran, S.S.; Ostrowski De Nuñez, M.; Overstreet, R.M.; Pérez-Ponce De León, G.; PortesSantos, C. 2016. Trematode diversity in freshwater fishes of the Globe, II: 'New World'. Systematic Parasitology, 93: 271-282.

Dogiel, V.A. 1961. Ecology of the parasites of freshwater fishes. In: Dogiel, V.A.; Petrushevski, G.K.; Polyanski, Y.I. (Ed.). Parasitology of fishes. University Press, Leningrad, p.1-47.

Eiras, J.C.; Takemoto, R.M.; Pavanelli, G.C. 2006. Métodos de estudo e técnicas laboratoriais em parasitologia de peixes. Eduem, Maringá, 199p.

EPE. 2011. Estudo de inventário hidrelétrico. Relatório final: Avaliação ambiental integrada. Empresa de Pesquisa Energética, vol. 1/2, $302 \mathrm{p}$.

Fischer, C.; Malta, J. C. O.; Varella. A.M.B. 2003. A fauna de parasitas do tambaqui, Colossoma macropomum (Cuvier, 1818) (Characiformes: Characidae) do médio rio Solimóes, estado do Amazonas (AM) e do baixo Rio Amazonas, estado do Pará (PA), e seu potencial como indicadores biológicos. Acta Amazonica, 33: 651-662.

Isaac, V.J.; Almeida, M.C.; Giarrizzo, T.; Deus, C.P.; Vale, R.; Klein, G.; Begossi, A. 2015. Food consumption as an indicator of the conservation of natural resources in riverine communities of the Brazilian Amazon. Anais da Academia Brasileira de Ciências, 87: 2229-2242.

Lizama, M.A.P.; Monkolski, J.G.; Carniel, M.K.; Costa, A.P.L. 2013. Mollusca, Hirudinea, Pentastomida e Acari parasitos de peixes. In: Pavanelli, G.C.; Takemoto, R.M.; Eiras, J.C (Org.). Parasitologia de peixes de água doce do Brasil. Eduem, Maringá, p.399-435.

Ludwig, J.A.; Reynolds, J.F. 1988. Statistical ecology: a primer on methods and computing. Wiley-Interscience, New York, 337p.

Magurran, A.E. 2004. Measuring biological diversity. Blackwell Science, Oxford, UK, 266p.
Malta, J.C.O. 1984. Os peixes de um lago de várzea da Amazônia Central (Lago Janauacá, Rio Solimôes) e suas relaçốes com os crustáceos ectoparasitas (Branchiura: Argulidae). Acta Amazonica, 14: 355-372.

Matos, L.V.; Oliveira, M.I.B.; Gomes, A.L.; Silva, G.S. 2017. Morphological and histochemical changes associated withmassive infection by Neoechinorhynchus buttnerae (Acanthocephala: Neoechinorhynchidae) in the farmed freshwater fish Colossoma macropomum Cuvier, 1818 from the Amazon State, Brazil. Parasitology Research, 116: 1029-1037.

Morais, I.S.; O'Sullivan, F.L.A. 2017. Biologia, habitat e cultivo do tambaqui Colossoma macropomum (Cuvier, 1816). Scientia Amazonia, 6: 81-93.

Morey, G.A.M.; Malta, J.C.O. 2016. Metazoários parasitas das narinas do tambaqui Colossoma macropomum (Cuvier, 1818) (Characiformes: Characidae) coletadas em Lagos de Várzea da Amazônia central, Brasil. Folia Amazónica, 25: 71-76.

Oliveira, M.S.B.; Gonçalves, R.A.; Ferreira, D.O.; Pinheiro, D.A.; Neves, L.R.; Dias, M.K.R.; Tavares-Dias, M. 2017. Metazoan parasite communities of wild Leporinus friderici (Characiformes: Anostomidae) from Amazon River system in Brazil. Studies on Neotropical Fauna and Environment, 52: 146-156.

Poulin, R. 2004. Macroecological patterns of species richness in parasite assemblages. Basic Applied Ecology, 5: 423-434.

Poulin, R.; Leung T.L.F. 2011. Body size, trophic level, and the use of fish as transmission routes by parasites. Oecologia, 166: 731738. Petrere Júnior, M.; Batista, V.S.; Freitas, C.E.C.; Almeida, O.T.; Surgik, A.C.S. 2007. O setor pesqueiro na Amazônia: análise da situaçấo atual e tendências do desenvolvimento a indústria da pesca. Provárzea, Manaus, 122p.

Rohde, K.; Hayward, C.; Heap, M. 1995. Aspects of the ecology of metazoan ectoparasites of marine fishes. Journal of Parasitology, 25: 945-970.

Rózsa, L.; Reiczigel, J.; Majoros, G. 2000. Quantifying parasites in samples of hosts. The Journal of Parasitology, 86: 228-232.

Soares, M.G.M.; Costa, E.L.; Siqueira-Souza, F.K.; Anjos, H.D.B.; Yamamoto, K.C.; Freitas, C.E.C. 2011. Peixes de lagos do médio Rio Solimões. Reggo Ediçôes, Manaus, 160p.

Takemoto, R.M.; Pavanelli, G.C.; Lizama, M.A.P.; Lacerda, A.C.F.; Yamada, F.H.; Moreira, L.H.A.; Ceschini, T.L.; Bellay, S. 2009. Diversity of parasites of fish from the upper Paraná River floodplain, Brazil. Brazilian Journal of Biology, 69: 691-705.

Tavares-Dias, M.; Gonçalves, R.A; Oliveira, M.S.B.; Neves, L.R. 2017. Ecological aspects of the parasites in Cichlasoma bimaculatum (Cichlidae), ornamental fish from the Brazilian Amazon. Acta Biológica Colombiana, 22: 175-180.

Zar, J. H. 2010. Biostatistical analysis. Prentice-Hall, New Jersey, $944 \mathrm{p}$.

RECEIVED:18/12/2017

ACCEPTED: $25 / 04 / 2018$

ASSOCIATE EDITOR: Linda Basson 